\title{
Women's Experiences of Induction of Labour With Low-dose Misoprostol Oral Tablets Compared With Slow-release Vaginal Insert. A Prospective Cohort Study Based on Questionnaires.
}

Karen Hell Hansen ( $\square$ karen_hell_hansen@hotmail.com )

Herlev Hospital https://orcid.org/0000-0002-1547-3156

Maria Jeppegaard

Hvidovre Hospital

Axelina Eriksson

Hvidovre Hospital

Sarah C. B. Jeppesen

Slagelse Hospital: Slagelse Sygehus

Lone Krebs

Hvidovre Hospital

Research article

Keywords: Patient experience, induced, induction, labour, angusta, oral misoprostol, misodel, slow-release misoprostol vaginal insert, nulliparous

Posted Date: December 17th, 2020

DOI: https://doi.org/10.21203/rs.3.rs-127692/v1

License: (c) (i) This work is licensed under a Creative Commons Attribution 4.0 International License. Read Full License 


\section{Abstract}

Background: The aim of this study was to compare nulliparous women's experiences of induction of labour with two different regimens of misoprostol.

Methods: In two different hospitals, nulliparous women undergoing medical induction of labour were asked to complete a questionnaire after delivery. We adapted a validated questionnaire regarding mood and feelings during induction of labour, experience of labour and experience of induction.

The questionnaire was completed by 123 (42.7\%) of 288 eligible women; 57 (46.3\%) had been allocated to oral misoprostol and $66(53.7 \%)$ to slow-release vaginal insert. An independent-samples T-test was used for comparison of parametric continuous variables and a Pearson chi-square test was used for categorical data.

Results: Women induced with oral misoprostol experienced a more painful induction of labour $(\mathrm{p}=0.019)$ and described feeling the length of stay at hospital as too long $(p=0.028)$. The overall experience of giving birth after induction of labour was reported as "good" among $87.8 \%$ of women induced with oral misoprostol compared to $72.7 \%$ of women induced with slow-release misoprostol vaginal insert $(p=0.039)$.

Conclusions: Induction with low-dose oral misoprostol in nulliparous women is associated with experience of more pain and longer duration but overall a more positive experience of labour compared with induction with slow-release misoprostol vaginal insert.

Trial registration: Clinicaltrials.gov ID: NCT02693587 on February 262,016.

EudraCT number 2020-000366-42 on 23 January 2020, retrospectively registered.

\section{Background}

Induction of labour is a common intervention. In Denmark, $24 \%$ of all deliveries are induced, with a $27 \%$ prevalence among nulliparous women [1]. Hence, it is of great importance to offer a regimen of induction that is not only safe and cost efficient but also provides the best possible experience for the parents during induction and labour.

In a recent study, we compared women induced with oral misoprostol to slow-release vaginal insert [2], finding that induction with vaginal misoprostol leads to faster deliveries and an increased risk of tachysystole but with similar perinatal outcomes and incidence of caesarean section or instrumental vaginal delivery. Low dose oral misoprostol appeared to be safe but was associated with an increased use of secondary methods of induction and a non-significant tendency of more intrapartum fever compared with vaginal misoprostol.

The knowledge of women's experiences with different regimens for induction of labour is limited. A Cochrane analysis in 2017 stated "We do not have sufficient evidence to know which induction methods are preferred by women" [3].

Most studies evaluate safety and efficacy in relation to induction but recently more attention has been paid to women's experiences of induction of labour, suggesting women's experience should be an important factor in the decision-making process $[4,5]$

Previous studies have found that women who experience induction of labour have an increased risk of a negative birth experience compared to women with a spontaneous onset of labour [6-8]. No previous studies have compared patients' experiences with regimens having very different efficacy in terms of duration from start of induction to delivery.

The aim of this study was to compare two populations of nulliparous women with unripe cervices regarding experiences of induction of labour and giving birth after induction with oral misoprostol and slow-release vaginal insert, respectively. 


\section{Methods}

Details of the study protocol have been reported elsewhere [2]. In short, all nulliparous women eligible for vaginal delivery and medical induction of labour were evaluated. Inclusion criteria were defined as singleton pregnancies, cephalic presentation of the fetus and a gestational age of 37 weeks or more. Artificial rupture of membranes was preferred for induction in women with favourable cervical conditions based on the midwife assessments. Exclusion criteria were defined as a previous uterine scar, suspicion of growth restriction of the fetus and prelabour rupture of membranes.

The study was conducted as part of a prospective cohort study localised in two different obstetric departments in the region of Zealand, Denmark. Data were collected from November 2015 to November 2017 with telephone follow up until May 2018.

The demographical population in the two departments were similar except for women with gestational diabetes mellitus (GDM) who were referred to one of the departments [2].

Local guidelines on induction of labour were elaborated for the two different departments defining dosage and criteria for discontinuation.

One department used a regime with $25 \mathrm{mcg}$ oral tablets of misoprostol (manufactured by Azanta) and the other department used a regime with 200 mcg slow-release vaginal insert of misoprostol (manufactured by Ferring).

The women induced with oral misoprostol were induced in an outpatient setting unless there was a medical indication for admitting the woman to the obstetric department. The women induced with vaginal misoprostol slow-release insert were hospitalized from the beginning of induction.

A total of 288 women were included in the study. All participating women were requested to complete a questionnaire on their experience of induction and labour after delivery. Only women who were able to complete the questionnaire in Danish could participate in the study.

Women who did not complete the questionnaire before leaving the hospital were contacted by telephone with a total of three times within the following few months and invited to participate. The questionnaires were then sent to the women by mail with an enclosed envelope with prepaid stamping.

The questionnaire was based on the items in the Wijma Delivery Expectancy/Experience Questionnaire which has previously been validated $[9,10]$. For the present study we elaborated 17 questions regarding the woman's moods and experiences of labour induction with most answers on a scale of 1 to 5; "Strongly agree", "agree", "neither nor/neutral", "disagree agree", "strongly disagree". Other questions had answers on a scale of 1 to 4; "very satisfied", "satisfied", "dissatisfied" or "very dissatisfied" or "very good", "good", "bad" or "very bad" and finally two questions with answers on a scale from 1 to 3.

Furthermore, the women were asked about the overall satisfaction of labour induction and some additional background data (Appendix).

All questionnaires were anonymous, and all women gave written or oral informed consent for collection of data for this study [2].

\section{Statistical analyses}

The statistical analyses were performed with SPSS Statistics (version 25.0). Normally distributed continuous data were reported as mean (SD). Percentage calculation was based on the number of available observations.

For the analysis of the experience of induction questions, we combined the answers; "Strongly agree" and "agree", as well as "disagree agree" and "strongly disagree". 
For the analysis of the questions about general satisfaction, we combined "very satisfied/very good" and "satisfied/good" as well as "dissatisfied/bad" and "very dissatisfied/very bad".

We used an independent-samples T-test comparison of parametric continuous variables and a Pearson chi-square test was used for categorical data.

We considered a p-value of $<0.05$ to indicate statistically significance.

\section{Ethical approval}

The study was performed in accordance with the guidelines of the Declaration of Helsinki and was approved by the Regional Ethics Committee (no. 50213) Regional Medicines Agency and the Danish Data Protection Agency (REG-81-2015). The original study was registered at clinical trials ID: NTC02693587 on February 26; 2016 and on EudraCT number 2020000366-42 on January 23; 2020, retrospectively registered.

Reporting of the results followed the STROBE guidelines.

\section{Results}

A total of 288 women in the cohort were eligible for the study. 123 women completed the questionnaire, of which 57 women were allocated to oral misoprostol and 66 women to slow release vaginal insert. 165 women did not respond the questionnaire (Fig. 1).

Baseline demographics were overall comparable between responders in the oral misoprostol and slow-release vaginal misoprostol groups except for GDM, BMI, Bishop score and time from induction to delivery. Women in the oral misoprostol group had a significantly higher BMI (30.5) compared with the slow-release vaginal misoprostol group $(27.6, p=0.05)$. Mean Bishop score in the oral group was 4.18 compared with 3.26 in the slow-release vaginal insert group $(p=0.03)$. Significantly more women induced with slow-release vaginal insert delivered within 24 hours of induction (59.1\%) compared with the oral misoprostol group (14\%) ( $p=0.000) .61 .4 \%$ of women induced with oral misoprostol spent more than 48 hours from induction to labour compared with $7.6 \%$ of the slow release vaginal insert group $(p=0.000)($ Table 1$)$.

Clinical characteristics between responders and non-responders of the questionnaire were similar, except for the distribution of GDM and the time from induction to delivery, with significantly more women with GDM found in the non-responder group induced by oral misoprostol (Table 1). Time from induction to delivery differs significantly between the responder and nonresponder group with more women in the responder group delivering within 24 hours $(p=0.02)$.

In a subgroup analysis excluding women with GDM, the groups were comparable except for significantly more women not delivering within 48 hours $(p=0.003)$ in the oral misoprostol group that responded to the questionnaire compared with the oral misoprostol non-responder group. (Table 2).

In the comparison of the oral misoprostol group and slow-release vaginal insert group, we found no significant differences regarding the women's emotions during induction, overall evaluation of the induction of labour and feelings about the labour being induced. (Tables 3 and 4).

We found a non-significant tendency of women being induced with slow-release vaginal insert more often reported a dissatisfaction with the duration of induction of labour with a total of $40.9 \%$ versus $26.3 \%$ of women being dissatisfied induced with oral misoprostol $(p=0.213)$.

Significantly more women induced with oral misoprostol reported time spent at the hospital during induction and labour as "not acceptable" or "too long" ( $p=0.03$ ). Also, they more often reported they could not handle the pain during induction of labour $(p=0.02)$ (Table 3$)$. 
The overall experience of giving birth after induction was significantly more positive in the group of women induced with oral misoprostol compared to the women induced with slow-release vaginal insert $(p=0.04)$ (Table 4).

\section{Discussion}

In this questionnaire-based prospective cohort study, we evaluated nulliparous women's experiences with induction of misoprostol in two hospitals with two different regimens and two different routes of administration; $25 \mathrm{mcg}$ oral tablets and $200 \mathrm{mcg}$ slow-release vaginal insert. A total of 123 of 288 women completed the questionnaire, corresponding to a response rate of $42.7 \%$. Although time from induction to birth was experienced as longer and more painful in women induced with oral misoprostol, their overall experience of birth was significantly more positive compared to women induced with slow-release vaginal insert.

To our knowledge, this is the first published evaluation comparing nulliparous women's experience with induction of labour with oral misoprostol to slow-release misoprostol vaginal insert in a homogenous population of women.

The present study is not without limitations. At the time we initiated this study there were no validated questionnaires on women's experiences of induction of labour.

The Wijma Delivery Expectancy/Experience Questionnaire is the most frequently used instrument when measuring expectations and fear of childbirth. When identifying women's experience of induction of labour, the questionnaire seems the most objective instrument. We elaborated the questionnaire for this study based on the themes raised by Wijma et al. [9]. However, it is a limitation that our questionnaire has not been validated.

Another limitation to the study is that the women were asked about their experience of the whole procedure after giving birth, and not solely regarding the experience of the induction. Since completion of a questionnaire is difficult during the active phase of labour, and because determination of the active phase is not realizable, we assume this to be the best solution. Furthermore, the questionnaire did not include questions on preferences of induction of labour in future pregnancies - nor questions on expectations, worries about the baby and the availability and quality of care received before and during labour, which previous reports have shown are relevant domains for women's overall experience of labour [11, 12].

A recent review concluded that women's experiences with induced labour can likely be improved by a communicative and patient-centred approach [4].

This study was also subject to methodological limitations as it was neither randomised nor blinded and set in two different hospitals. However, apart from inclusion of women with GDM, the two populations were comparable and a sub analysis excluding women with GDM did not change the results. As only women who were able to complete the questionnaire in Danish could participate, and as the study is from only two centres, there is a risk that the population studied is too homogenous in this aspect.

Another limitation of the study was the difference in in- versus out-patient regimen for induction, where women's experience may reflect the opportunity to leave the hospital more than the method as such. Knowledge of women's preferences in this aspect is limited [13]. Use of oral misoprostol in an outpatient setting could be more comparable to a spontaneous start of labour, where women usually spend the time during the latent phase outside hospital. However, it is also possible that some women may be more anxious in the outpatient setting because of the uncertainties surrounding induction of labour and practicalities.

Finally, a limitation is the response rate in the two groups. More women in the slow-release vaginal insert group (53\%) than in the oral misoprostol group (46\%) participated. Although no difference in demographic characteristics between responders and non-responders were found except for faster deliveries (within 24 hours) in the responding group $(p=0.02)$, the difference in response rate of the groups could result in a potential risk of biased results. An obvious reason could be that

Page 5/18 
the women were not informed about the study prior to induction and when receiving the questionnaire immediately after delivery, they were more likely to forget or reject to complete the questionnaire as they had just become mothers.

Previous studies investigating women's experience of induction achieved a response rate of $55.1 \%$ [14] and 70\% [15], the latter informed orally and written about the study at least one day before admission.

In the present study we found that time from induction to delivery had no influence on women's birth experience or their experience of induction of labour when comparing women delivering within 24 hours to women with more than 48 hours from induction to birth.

It seems plausible that the risk of secondary interventions increases with time interval between induction start and delivery, thereby creating more contact moments with the attending midwife that could lead to more satisfaction with the induction experience.

The relative risk of hyperstimulation is expected to be increased with the use of slow-release vaginal insert, as demonstrated in our recent study and other $[2,16,17]$. Hyperstimulation could possibly affect the experience of labour, which supports our finding of the vaginal insert group having a more negative experience of labour compared with the oral group.

A previous randomized clinical trial on oral versus vaginal misoprostol found no difference in the average interval from the first dose of misoprostol to delivery. Still $14 \%$ of women in the vaginal group versus $7.5 \%$ in the oral group were dissatisfied with the use of misoprostol [18].

Other studies found no difference in labour experience and no difference in time from induction to vaginal delivery with vaginal and oral misoprostol [19].

Research on women's experiences with a fast versus a slow delivery is sparse. Neither a fast nor slow delivery seems to make a difference in the experience of giving birth nor does it seem to be important for the women's overall experience of labour and satisfaction with the procedure.

On the other hand, induced women might be less satisfied in general because the experience of the time of induction diverges from the women's expectations.

Experiences differ among pregnant women. What is important for one woman may be less important for another. Furthermore, clinical factors such as gestational age, BMI, parity, indication for induction, ripening of cervix could be factors to consider when designing individual regimens for induction. Slow-release vaginal misoprostol insert has some advantages compared with oral misoprostol and there may be some individuals who could benefit from this method of induction, for instance, when induction of labour is expected to be particularly difficult and/or prolonged.

\section{Conclusion}

In this study we found that the experience of induction of labour in at term nulliparous women with oral misoprostol compared to vaginal inserts was comparable.

An overall better experience of labour was found among women induced with oral misoprostol in an out-patient setting compared to slow-release vaginal misoprostol in an in-patient setting.

Duration from induction of labour to delivery does not seem important to women's experience.

\section{Abbreviations}

GDM: gestational diabetes mellitus 


\section{Declarations}

\section{Ethics approval and consent to participate}

The study was performed in accordance with the guidelines of the Declaration of Helsinki and was approved by the Regional Ethics Committee (no. 50213), Regional Medicines Agency and the Danish Data Protection Agency (REG-81-2015). The study was registered at clinicaltrials.gov ID: NCT02693587 on February 26; 2016 and on EudraCT number 2020-000366-42 on January $23 ; 2020$, retrospectively registered.

The use of the two different regimens for induction of labour was approved by the Regional Medicines Agency as standard regimens for the two different departments, therefore individual consent for the choice of medication was not required besides informed consent for induction of labour in general.

All women who participated in the study were asked to fill out a questionnaire abort their birth experience before they left the department. In the end of this questionnaire they were asked for permission to collect information from their medical record.

If they did not fill out the questionnaire, they were contacted by telephone and asked to answer the same questions including the question about collecting information from their medical record. The Regional Ethics committee approved the use of verbal consent for data collection, for patients contacted by telephone.

All patients included in this study provided informed consent (verbal or written) to access their medical records, and this was collected and registered before data-collection was commenced, as approved by the ethics committee. The researcher accessing the information was/is an authorised health care professional.

\section{Consent for publication}

Not applicable.

\section{Availability of data and materials}

All data analysed during this study are included in this published article. All generated raw data used for the analysis was deleted after completion of analysis as advised from the data protection authorities.

\section{Competing interests}

The authors declare that they have no competing interests.

\section{Funding}

Region Zealand Health Scientific Research Foundation supported the study financially.

\section{Author's Contributions}

$\mathrm{AE}$ and $\mathrm{LK}$ contributed to the study design, $\mathrm{AE}$ and $\mathrm{SJ}$ contributed to the acquisition of data retrieval, $\mathrm{KH}, \mathrm{MJ}$ and $\mathrm{LK}$ analysed and interpreted the data. KH drafted the manuscript with revisions from AE, SJ, MJ and LK. All authors approved the final edition and are accountable for all aspects of the work.

\section{Acknowledgements}

Not applicable.

\section{Disclosure of interests:}

All authors declare no conflict of interest. 


\section{References}

1. http://end2019.esundhed.dk/sundhedsregistre/MFR/Sider/MFR06A.aspx. Accessed 11062020 n.d.

2. Eriksson A, Jeppesen S, Krebs L. Induction of labour in nulliparous women- quick or slow: A cohort study comparing slow-release vaginal insert with low-dose misoprostol oral tablets. BMC Pregnancy and Childbirth 2020;20(1):79. https://doi.org/10.1186/s12884-020-2770-0

3. Vogel JP, Osoti AO, Kelly AJ, Livio S, Norman JE, Alfirevic Z. Pharmacological and mechanical interventions for labour induction in outpatient settings. Cochrane Database Syst Rev 2017; 9(9):CD007701. https://doi.org/10.1002/14651858.CD007701.pub3.

4. Coates R, Cupples G, Scamell A, McCourt C. Women's experiences of induction of labour: Qualitative systematic review and thematic synthesis. Midwifery 2019; 69:17-28. https://doi.org/10.1016/j.midw.2018.10.013.

5. Alfirevic Z, Aflaifel N, Weeks A. Oral misoprostol for induction of labour. Cochrane Database Syst Rev 2014;2014(6):CD001338. https://doi.org/10.1002/14651858.CD001338.pub3.

6. Hildingsson I, Karlström A, Nystedt A. Women's experiences of induction of labour - Findings from a Swedish regional study. Aust N Z J Obstet Gynaecol 2011;51(2):151-7. https://doi.org/10.1111/j.1479-828X.2010.01262.x.

7. Lou S, Hvidman L, Uldbjerg N, Neumann L, Jensen TF, Haben JG, et al. Women's experiences of postterm induction of labor: A systematic review of qualitative studies. Birth 2019; 46(3):400-410. https://doi.org/10.1111/birt.12412.

8. Shetty A, Burt R, Rice P, Templeton A. Women's perceptions, expectations and satisfaction with induced labour - A questionnaire-based study. Eur J Obstet Gynecol Reprod Biol 2005; 123(1):56-61.

https://doi.org/10.1016/j.ejogrb.2005.03.004.

9. Wijma K, Wijma B, Zar M. Psychometric aspects of the W-DEQ; A new questionnaire for the measurement of fear of childbirth. J Psychosom Obstet Gynaecol 1998;19(2):84-97. https://doi.org/10.3109/01674829809048501.

10. Garthus-Niegel S, Størksen HT, Torgersen L, von Soest T, Eberhard-Gran M. The Wijma Delivery Expectancy/Experience Questionnaire a factor analytic study. J Psychosom Obstet Gynaecol 2011;32(3):160-3.

https://doi.org/10.3109/0167482X.2011.573110.

11. Gärtner FR, Freeman LM, Rijnders ME, Middeldorp JM, Bloemenkamp KWM, Stiggelbout AM, et al. A comprehensive representation of the birth-experience: Identification and prioritization of birth-specific domains based on a mixedmethod design. BMC Pregnancy and Childbirth 2014;14:147. https://doi.org/10.1186/1471-2393-14-147.

12. Simkin P. The experience of maternity in a woman's life. J Obstet Gynecol Neonatal Nurs 1996;25(3):247-52. https://doi.org/10.1111/j.1552-6909.1996.tb02432.x.

13. Kelly AJ, Alfirevic Z, Ghosh A. Outpatient versus inpatient induction of labour for improving birth outcomes. Cochrane Database Syst Rev 2013;(11):CD007372. https://doi.org/10.1002/14651858.CD007372.pub3.

14. Henderson J, Redshaw M. Women's experience of induction of labor: A mixed methods study. Acta Obstet Gynecol Scand 2013;92(10):1159-67. https://doi.org/10.1111/aogs.12211.

15. Ten Eikelder MLG, van de Meent MM, Mast K, Rengerink KO, Jozwiak M, de Graaf IM, et al. Women's Experiences with and Preference for Induction of Labor with Oral Misoprostol or Foley Catheter at Term. Am J Perinatol 2017;34(2):138146. https://doi.org/10.1055/s-0036-1584523.

16. Wing DA, Miller H, Parker L, Powers BL, Rayburn WF. Misoprostol vaginal insert for successful labor induction: $A$ randomized controlled trial. Obstet Gynecol 2011;117(3):533-41. https://doi.org/10.1097/AOG.0b013e318209d669.

17. Hofmeyr GJ, Gülmezoglu AM, Pileggi C. Vaginal misoprostol for cervical ripening and induction of labour. Cochrane Database Syst Rev 2010;2010(10):CD000941. https://doi.org/10.1002/14651858.cd000941.pub2.

18. Colon I, Clawson K, Taslimi M, Druzin M. Prospective randomized clinical trial of inpatient cervical ripening with stepwise oral misoprostol versus vaginal misoprostol. Am J Obstet Gynecol 2005;192(3):747-52.

https://doi.org/10.1016/j.ajog.2004.09.068. 
19. Wallström T, Strandberg M, Gemzell-Danielsson K, Pilo C, Jarnbert-Pettersson H, Friman-Mathiasson M, et al. Slowrelease vaginal insert of misoprostol versus orally administrated solution of misoprostol for the induction of labour in primiparous term pregnant women: a randomised controlled trial. BJOG 2019;126(9):1148-1155.

https://doi.org/10.1111/1471-0528.15796.

\section{Tables}


Table 1

Characteristics of responders and non-responders to the questionnaire

\begin{tabular}{|c|c|c|c|c|c|c|c|}
\hline Characteristic & Responders ( & $=123)$ & & $\begin{array}{l}\text { Nonr } \\
165)\end{array}$ & sponders ( $\mathrm{n}=$ & & $\begin{array}{l}\text { p-value } \\
\text { responders vs. } \\
\text { nonresponders }\end{array}$ \\
\hline $\begin{array}{l}\text { Method of } \\
\text { induction }\end{array}$ & $\begin{array}{l}\text { Oral } \\
\text { misoprostol } \\
(n=57)\end{array}$ & $\begin{array}{l}\text { Vaginal } \\
\text { misoprostol } \\
(n=66)\end{array}$ & $\begin{array}{l}\mathrm{p} \text {-value } \\
\text { oral vs. } \\
\text { vaginal }\end{array}$ & $\begin{array}{l}\text { Oral } \\
\text { misoprostol } \\
(n=115)\end{array}$ & $\begin{array}{l}\text { Vaginal } \\
\text { misoprostol } \\
(n=50)\end{array}$ & $\begin{array}{l}\mathrm{p} \text {-value } \\
\text { oral vs. } \\
\text { vaginal }\end{array}$ & \\
\hline $\begin{array}{l}\text { Maternal age } \\
\text { (years), mean (SD) }\end{array}$ & $28.2(5)$ & $28.5(5.6)$ & 0.760 & $27.2(5.1)$ & $26.9(4.7)$ & 0.666 & 0.053 \\
\hline $\begin{array}{l}\mathrm{BMI}\left(\mathrm{kg} / \mathrm{m}^{2}\right) \text {, mean } \\
(\mathrm{SD})\end{array}$ & $30.5(8.3)^{a}$ & $27.6(6.9)$ & $0.050 *$ & $29,1(7,4)^{b}$ & $28(7.6)^{c}$ & 0.384 & 0.156 \\
\hline $\begin{array}{l}\text { Caesarean Section, } \\
\mathrm{n}(\%)\end{array}$ & $\begin{array}{l}N=16 \\
(28.1 \%)\end{array}$ & $\begin{array}{l}N=23 \\
(34.8 \%)\end{array}$ & 0.420 & 79 (68.7\%) & $36(72 \%)$ & 0.728 & 0.739 \\
\hline $\begin{array}{l}\text { Maternal } \\
\text { educational level, n } \\
(\%)\end{array}$ & $6(10.7 \%)^{d}$ & $6(9.1 \%)$ & 0.766 & - & - & - & - \\
\hline$<10$ years & $26(46.4 \%)$ & 35 (53.0\%) & & & & & \\
\hline $\begin{array}{l}\text { 10-15 years } \\
>15 \text { years }\end{array}$ & $24(42.9 \%)$ & $25(37.9 \%)$ & & & & & \\
\hline Cigarette use, n (\%) & $7(12.3 \%)$ & $10(15.2 \%)$ & 0.645 & $18(15.7 \%)$ & $9(18.0 \%)$ & 0.708 & 0.553 \\
\hline $\begin{array}{l}\text { Pre-existing } \\
\text { medical conditions, } \\
\mathrm{n}(\%)\end{array}$ & $7(12.3 \%)$ & $7(10.62 \%)$ & 0.771 & $15(13.0 \%)$ & $5(10.0 \%)$ & 0.582 & 0.848 \\
\hline $\begin{array}{l}\text { Pre-existing } \\
\text { psychiatrical } \\
\text { conditions, } \mathrm{n}(\%)\end{array}$ & $3(5.26 \%)$ & $5(7.56 \%)$ & 0.630 & $11(9.6 \%)$ & $5(10.0 \%)$ & 0.932 & 0.538 \\
\hline
\end{tabular}

${ }^{a}$ data on $n=44,{ }^{\text {b }}$ data on $n=106$, ${ }^{c}$ data on $n=49$, ddata on $n=56$, e including 5 with GDM + other diagnosis, ${ }^{f}$ including 3 with GDM + other diagnosis, hdata on 113 , idata on $n=25$,

${ }^{*} \mathrm{p}<0.05$ 


\begin{tabular}{|c|c|c|c|c|c|c|c|}
\hline \multirow{2}{*}{$\begin{array}{l}\text { Characteristic } \\
\begin{array}{l}\text { Pregnancy-related } \\
\text { medical conditions, } \\
\text { n (\%) }\end{array}\end{array}$} & \multicolumn{3}{|c|}{ Responders $(n=123)$} & \multicolumn{3}{|c|}{$\begin{array}{l}\text { Nonresponders }(n= \\
\text { 165) }\end{array}$} & \multirow{2}{*}{$\begin{array}{l}\text { p-value } \\
\text { responders vs. } \\
\text { nonresponders }\end{array}$} \\
\hline & $22(38.6 \%)$ & $17(25.8 \%)$ & 0.220 & $69(60.0 \%)$ & $14(28.0 \%)$ & $0.02 *$ & \\
\hline GDM, $n(\%)$ & $2(9.1 \%)$ & $1(5.9 \%)$ & & $27(39.1 \%)$ & - & & \\
\hline Preeclampsia (\%) & $6(27.2 \%)$ & $11(64.7 \%)$ & & $16(23.2 \%)$ & $5(35.7 \%)$ & & \\
\hline Hypertension (\%) & $2(9.1 \%)$ & $2(11.8 \%)$ & & $7(10.4 \%)$ & - & & \\
\hline Intrahepatic & $1(4.5 \%)$ & $1(5.9 \%)$ & & $4(5.8 \%)$ & $2(14.3 \%)$ & & \\
\hline cholestasis (\%) & $11(50 \%)^{e}$ & $2(11.8 \%)$ & & $15(21.7 \%)^{f}$ & $7(50 \%)$ & & \\
\hline \multicolumn{8}{|l|}{ Others, $n(\%)$} \\
\hline \multirow{2}{*}{$\begin{array}{l}\text { Indication for } \\
\text { induction, } \mathrm{n}(\%)\end{array}$} & $57(100 \%)$ & $66(100 \%)$ & 0.075 & $115(100 \%)$ & $50(100 \%)$ & $0.021^{*}$ & 0.764 \\
\hline & $44(77.2 \%)$ & $45(68.2 \%)$ & & $91(79.1 \%)$ & $31(62.0 \%)$ & & \\
\hline Post-dates & $\begin{array}{l}13 \\
(22.80 \%)\end{array}$ & $21(31.8 \%)$ & & $24(20.9 \%)$ & $19(38.0 \%)$ & & \\
\hline Other & - & & & & & & \\
\hline $\begin{array}{l}\text { Bishop score, } \\
\text { mean (SD) }\end{array}$ & $\begin{array}{l}4.18 \\
(1.770)^{d}\end{array}$ & $\begin{array}{l}3.26 \\
(1.572)\end{array}$ & $0.03^{\star}$ & $\begin{array}{l}4.40(2.262 \\
)^{\mathrm{h}}\end{array}$ & $\begin{array}{l}3.16 \\
(1.405)^{c}\end{array}$ & $0.001^{*}$ & 0.143 \\
\hline $\begin{array}{l}\text { Gestational age at } \\
\text { delivery }(w+d) \text {, } \\
\text { mean }(S D)\end{array}$ & $\begin{array}{l}40+6(1+ \\
4)\end{array}$ & $\begin{array}{l}40+6(1+ \\
3)\end{array}$ & 0.838 & $\begin{array}{l}40+5(1+ \\
2)\end{array}$ & $\begin{array}{l}40+4(1+ \\
4)\end{array}$ & 0.575 & 0.43 \\
\hline $\begin{array}{l}\text { Birthweight (g), } \\
\text { mean (SD) }\end{array}$ & $3706(528)^{i}$ & $3697(526)$ & 0.936 & 3619 (532) & 3556 (485) & 0.530 & 0.136 \\
\hline \multicolumn{8}{|l|}{$\begin{array}{l}\text { Post partum } \\
\text { hemorrhage } \mathrm{n}(\%)\end{array}$} \\
\hline \multirow{2}{*}{$\begin{array}{l}500-1000 \mathrm{ml} \\
>1000 \mathrm{ml}\end{array}$} & $10(17.5 \%)$ & $9(13.6 \%)$ & 0.389 & $16(13.9 \%)$ & $8(16.0 \%)$ & 0.136 & 0.777 \\
\hline & $4(7.0 \%)$ & $7(10.6 \%)$ & & $14(12.2 \%)$ & $2(4.0 \%)$ & & \\
\hline $\begin{array}{l}\text { Time from } \\
\text { induction to } \\
\text { delivery (minutes), } \\
\text { mean (SD) }\end{array}$ & $\begin{array}{l}3107.89 \\
(1363.10)\end{array}$ & $\begin{array}{l}1420.27 \\
(824.65)\end{array}$ & $0.000 *$ & $\begin{array}{l}2925.39 \\
(1584.18)\end{array}$ & $\begin{array}{l}1683.22 \\
(1128.13)\end{array}$ & $0.004^{*}$ & 0.463 \\
\hline$<24$ hours, $n(\%)$ & $8(n=14 \%)$ & $\begin{array}{l}39(n= \\
59.1 \%)\end{array}$ & $0.000 *$ & $\begin{array}{l}15(n= \\
13 \%)\end{array}$ & $\begin{array}{l}27(n= \\
54 \%)\end{array}$ & $0.000 *$ & $0.020 *$ \\
\hline$>24$ hours, $n(\%)$ & $\begin{array}{l}49(n= \\
86 \%)\end{array}$ & $\begin{array}{l}27(n= \\
40.9 \%)\end{array}$ & $0.000 *$ & $\begin{array}{l}100(n= \\
87 \%)\end{array}$ & $\begin{array}{l}23(n= \\
46 \%)\end{array}$ & $0.000 *$ & $0.020 *$ \\
\hline$<48$ hours, $n(\%)$ & $\begin{array}{l}22(n= \\
38.6 \%)\end{array}$ & $\begin{array}{l}61(\mathrm{n}= \\
92.4 \%)\end{array}$ & $0.000^{*}$ & $\begin{array}{l}67(\mathrm{n}= \\
58.3 \%)\end{array}$ & $\begin{array}{l}43(n= \\
86 \%)\end{array}$ & $0.001^{*}$ & 0.885 \\
\hline$>48$ hours, $n(\%)$ & $\begin{array}{l}35(n= \\
61.4 \%)\end{array}$ & $5(n=7.6 \%)$ & $0.000 *$ & $\begin{array}{l}48(n= \\
41.7 \%)\end{array}$ & $7(n=14 \%)$ & $0.001 *$ & 0.885 \\
\hline \multicolumn{8}{|c|}{$\begin{array}{l}{ }^{a} \text { data on } n=44,{ }^{b} \text { data on } n=106,{ }^{c} \text { data on } n=49 \text {, data on } n=56 \text {, e including } 5 \text { with GDM + other diagnosis, }{ }^{f} \text { including } 3 \\
\text { with GDM + other diagnosis, }{ }^{h} \text { data on } 113 \text {, 'data on } n=25 \text {, }\end{array}$} \\
\hline$*_{p}<0.05$ & & & & & & & \\
\hline
\end{tabular}


Page 12/18 
Table 2

Characteristics on responders and non-responders to the questionnaire excluding women with gestational diabetes

\begin{tabular}{|c|c|c|c|}
\hline Characteristic & Responders & Nonresponders & \\
\hline Method of Induction & $\begin{array}{l}\text { Oral excluding GDM }(\mathrm{n}= \\
55)\end{array}$ & $\begin{array}{l}\text { Oral excluding GDM }(\mathrm{n}= \\
88)\end{array}$ & $\begin{array}{l}\mathrm{p}- \\
\text { value }\end{array}$ \\
\hline Maternal age (years), mean (SD) & $28(5)$ & $27(5)$ & 0.085 \\
\hline BMI, mean (SD) & $30.7(8.4)$ & $28.6(7.4)$ & 0.157 \\
\hline Caesarean Section, n (\%) & $15(27.3 \%)$ & $26(29.5 \%)$ & 0.738 \\
\hline \multicolumn{4}{|l|}{ Maternal educational level, n (\%) } \\
\hline$<10$ years & $6(10.9 \%)$ & - & - \\
\hline $10-15$ years & $25(45.5 \%)$ & & \\
\hline$>15$ years & $23(41.8 \%)^{a}$ & & \\
\hline Cigarette use, n (\%) & $6(10.9 \%)$ & $14(15.9 \%)$ & 0.402 \\
\hline Pre-existing medical conditions, n (\%) & $7(12.7 \%)$ & $12(13.6 \%)$ & 0.876 \\
\hline Pre-existing psychiatrical conditions, n (\%) & $3(5.9 \%)^{b}$ & $9(10.8 \%)^{c}$ & 0.329 \\
\hline Pregnancy-related medical conditions, n (\%) & $20(36.4 \%)$ & $42(47.7 \%)$ & 0.239 \\
\hline Preeclampsia (\%) & $6(30 \%)$ & $16(38.1 \%)$ & \\
\hline Hypertension (\%) & $2(10 \%)$ & $7(16.7 \%)$ & \\
\hline Intrahepatic cholestasis (\%) & $1(5 \%)$ & $4(9.5 \%)$ & \\
\hline Others, $n(\%)$ & $11(55 \%)$ & $15(35.7 \%)$ & \\
\hline Indication for induction, n (\%) & 55 & 88 & 0.738 \\
\hline Medical/obstetrical & $42(76.4 \%)$ & $65(73.9 \%)$ & \\
\hline Post-dates & $13(23.6 \%)$ & $23(26.1 \%)$ & \\
\hline Bishop score, mean (SD) & $4.1(1.8)^{d}$ & $4.5(2.3)^{\mathrm{e}}$ & 0.353 \\
\hline Gestational age at delivery $(w+d)$, mean $(S D)$ & $41+0(1+3)$ & $40+6(1+3)$ & 0.797 \\
\hline Birthweight (g), mean (SD) & $3720(534.5)^{f}$ & $3580(541.3)^{g}$ & 0.308 \\
\hline \multicolumn{4}{|l|}{ Post partum hemorrhage, $\mathrm{n}(\%)$} \\
\hline $500-1000 \mathrm{ml}$ & $10(18.2 \%)$ & $11(12.5 \%)$ & 0.567 \\
\hline$>1000 \mathrm{ml}$ & $4(7.3 \%)$ & $8(9.1 \%)$ & \\
\hline \multicolumn{4}{|l|}{$\begin{array}{l}\text { Time from induction to delivery (minutes), mean } \\
\text { (SD) }\end{array}$} \\
\hline$<24$ hours, $n(\%)$ & $7(12.7 \%)$ & $14(15.9 \%)$ & 0.601 \\
\hline$>24$ hours, $n(\%)$ & $48(87.3 \%)$ & $74(84.1 \%)$ & 0.601 \\
\hline
\end{tabular}

${ }^{a}$ data on $n=54,{ }^{b}$ data on $n=51,{ }^{c}$ data on $n=83,{ }^{d}$ data on $n=54,{ }^{e}$ data on $n=86,{ }^{f}$ data on $n=24,{ }^{g}$ data on $n=45$
${ }^{*} p<0.05$ 


\begin{tabular}{|c|c|c|c|}
\hline Characteristic & Responders & Nonrespond & \\
\hline$<48$ hours, $n(\%)$ & $21(38.2 \%)$ & $56(63.6 \%)$ & $0.003^{\star}$ \\
\hline$>48$ hours, $n(\%)$ & $34(61.8 \%)$ & 32 (36.4\%) & $0.003^{\star}$ \\
\hline \multicolumn{4}{|c|}{${ }^{a}$ data on $n=54$, ${ }^{b}$ data on $n=51,{ }^{c}$ data on $n=83,{ }^{d}$ data on $n=54$, ${ }^{e}$ data on $n=86,{ }^{f}$ data on $n=24$, ${ }^{g}$ data on $n=45$} \\
\hline \multicolumn{4}{|l|}{${ }^{*} p<0.05$} \\
\hline
\end{tabular}


Table 3

Women's experience of induction of labour

\begin{tabular}{|c|c|c|c|c|c|c|c|}
\hline \multirow[b]{2}{*}{ Question } & \multicolumn{3}{|c|}{$\begin{array}{l}\text { Oral Misoprostol } \\
(n=57)\end{array}$} & \multicolumn{2}{|c|}{$\begin{array}{l}\text { Vaginal } \\
\text { Misoprostol } \\
(n=66)\end{array}$} & \multirow[b]{2}{*}{ Too long } & \multirow[b]{2}{*}{ p-value } \\
\hline & Acceptable & $\begin{array}{l}\text { Too } \\
\text { short }\end{array}$ & Too long & Acceptable & Too short & & \\
\hline \multirow[t]{2}{*}{$\begin{array}{l}\text { "How did you experience the } \\
\text { length of your hospital stay } \\
\text { during induction?" }\end{array}$} & $2(3.5 \%)$ & $\begin{array}{l}36 \\
(63.2 \%)\end{array}$ & $\begin{array}{l}19 \\
(33.3 \%)\end{array}$ & $5(7.6 \%)$ & $\begin{array}{l}52 \\
(78.8 \%)\end{array}$ & $\begin{array}{l}9 \\
(13.6 \%)\end{array}$ & $0.028 *$ \\
\hline & Acceptable & Too few & $\begin{array}{l}\text { Too } \\
\text { many }\end{array}$ & Acceptable & Too few & $\begin{array}{l}\text { Too } \\
\text { many }\end{array}$ & \\
\hline \multirow{2}{*}{$\begin{array}{l}\text { "How did you experience the } \\
\text { number of midwife } \\
\text { examinations during induction } \\
\text { and labour?" }\end{array}$} & $1^{\mathrm{a}}(1.8 \%)$ & $\begin{array}{l}50 \\
(89.3 \%)\end{array}$ & $5(8.9 \%)$ & $3(4.5 \%)$ & $\begin{array}{l}51 \\
(77.3 \%)\end{array}$ & $\begin{array}{l}12 \\
(18.2 \%)\end{array}$ & 0.213 \\
\hline & Agree & $\begin{array}{l}\text { Neither } \\
\text { nor }\end{array}$ & Disagree & Agree & $\begin{array}{l}\text { Neither } \\
\text { nor }\end{array}$ & Disagree & \\
\hline $\begin{array}{l}\text { "I felt I could handle the pain } \\
\text { during induction" }\end{array}$ & $5(8.8 \%)$ & $\begin{array}{l}12 \\
(21.1 \%)\end{array}$ & $\begin{array}{l}40 \\
(70.2 \%)\end{array}$ & $19(28.8 \%)$ & $\begin{array}{l}12 \\
(18.2 \%)\end{array}$ & $\begin{array}{l}35 \\
(53 \%)\end{array}$ & $0.019 *$ \\
\hline $\begin{array}{l}\text { "I felt helpless during } \\
\text { induction" }\end{array}$ & $\begin{array}{l}31 \\
(54.4 \%)\end{array}$ & $\begin{array}{l}18 \\
(31.6 \%)\end{array}$ & $\begin{array}{l}8 \\
(14.0 \%)\end{array}$ & $39(59.1 \%)$ & $\begin{array}{l}12 \\
(18.2 \%)\end{array}$ & $\begin{array}{l}15 \\
(22.7 \%)\end{array}$ & 0.165 \\
\hline $\begin{array}{l}\text { "I felt positive during } \\
\text { induction" }\end{array}$ & $10(17.5 \%)$ & $\begin{array}{l}13 \\
(22.8 \%)\end{array}$ & $\begin{array}{l}34(59.6 \\
\%)\end{array}$ & $20(30.3 \%)$ & $\begin{array}{l}15 \\
(22.7 \%)\end{array}$ & $\begin{array}{l}31 \\
(47.0 \%)\end{array}$ & 0.226 \\
\hline $\begin{array}{l}\text { "I felt I would never come out } \\
\text { of it }\end{array}$ & $32(56.1 \%)$ & $\begin{array}{l}9 \\
(15.8 \%)\end{array}$ & $\begin{array}{l}16 \\
(28.1 \%)\end{array}$ & $29(43.9 \%)$ & $1218.2 \%)$ & $\begin{array}{l}25 \\
(37.9 \%)\end{array}$ & 0.386 \\
\hline $\begin{array}{l}\text { "I felt I could make it during } \\
\text { induction" }\end{array}$ & $11(19.3 \%)$ & $\begin{array}{l}13 \\
(22.8 \%)\end{array}$ & $\begin{array}{l}33 \\
(57.9 \%)\end{array}$ & $17(25.8 \%)$ & $\begin{array}{l}17 \\
(25.8 \%)\end{array}$ & $\begin{array}{l}32 \\
(48.5 \%)\end{array}$ & 0.554 \\
\hline $\begin{array}{l}\text { "I felt I no longer wanted to } \\
\text { participate during induction" }\end{array}$ & $35(61.4 \%)$ & $\begin{array}{l}9 \\
(15.8 \%)\end{array}$ & $\begin{array}{l}13 \\
(22.8 \%)\end{array}$ & $35(53.0 \%)$ & $8(12.1 \%)$ & $\begin{array}{l}23 \\
(34.8 \%)\end{array}$ & 0.335 \\
\hline "I felt happy during induction" & $8(14.0 \%)$ & $\begin{array}{l}13 \\
(22.8 \%)\end{array}$ & $\begin{array}{l}36 \\
(63.2 \%)\end{array}$ & $17(25.8 \%)$ & $\begin{array}{l}16 \\
(24.2 \%)\end{array}$ & $\begin{array}{l}33 \\
(50.0 \%)\end{array}$ & 0.219 \\
\hline $\begin{array}{l}\text { "I felt like giving up during } \\
\text { induction" }\end{array}$ & $31(54.4 \%)$ & $\begin{array}{l}10 \\
(17.5 \%)\end{array}$ & $\begin{array}{l}16 \\
(28.1 \%)\end{array}$ & $38(57.6 \%)$ & $\begin{array}{l}12 \\
(18.2 \%)\end{array}$ & $\begin{array}{l}16 \\
(24.2 \%)\end{array}$ & 0.889 \\
\hline $\begin{array}{l}\text { "I felt induction took really } \\
\text { long time" }\end{array}$ & $15(26.3 \%)$ & $\begin{array}{l}8 \\
(14.0 \%)\end{array}$ & $\begin{array}{l}34 \\
(59.6 \%)\end{array}$ & 27 (40.9\%) & $9(13.6 \%)$ & $\begin{array}{l}30 \\
(45.5 \%)\end{array}$ & 0.213 \\
\hline \multirow[t]{2}{*}{ "I felt calm during induction" } & $12(21.1 \%)$ & $\begin{array}{l}20 \\
(35.1 \%)\end{array}$ & $\begin{array}{l}25 \\
(43.9 \%)\end{array}$ & $16(24.2 \%)$ & $\begin{array}{l}27 \\
(40.9 \%)\end{array}$ & $\begin{array}{l}23 \\
(34.8 \%)\end{array}$ & 0.593 \\
\hline & Good & Average & Bad & Good & Average & Bad & \\
\hline \multirow{2}{*}{$\begin{array}{l}\text { Compared to other women } \\
\text { giving birth, how did you } \\
\text { experience your induction of } \\
\text { labour process? }\end{array}$} & $33(57.9 \%)$ & $\begin{array}{l}16 \\
(28.1 \%)\end{array}$ & $\begin{array}{l}8 \\
(14.0 \%)\end{array}$ & $36(54.5 \%)$ & $\begin{array}{l}22 \\
(33.3 \%)\end{array}$ & $\begin{array}{l}8 \\
(12.1 \%)\end{array}$ & 0.810 \\
\hline & Easier & Average & Harder & Easier & Average & Harder & \\
\hline $\begin{array}{l}\text { "How do you evaluate your } \\
\text { induction of labour? }\end{array}$ & $\begin{array}{l}39^{a} \\
(69.6 \%)\end{array}$ & $\begin{array}{l}7 \\
(12.5 \%)\end{array}$ & $\begin{array}{l}10 \\
(17.9 \%)\end{array}$ & $40(60.6 \%)$ & $\begin{array}{l}13 \\
(19.7 \%)\end{array}$ & $\begin{array}{l}13 \\
(19.7 \%)\end{array}$ & 0.498 \\
\hline
\end{tabular}


aData on $\mathrm{n}=56$

${ }^{*} \mathrm{p}<0.05$

Table 4

General satisfaction with the induction and delivery procedure

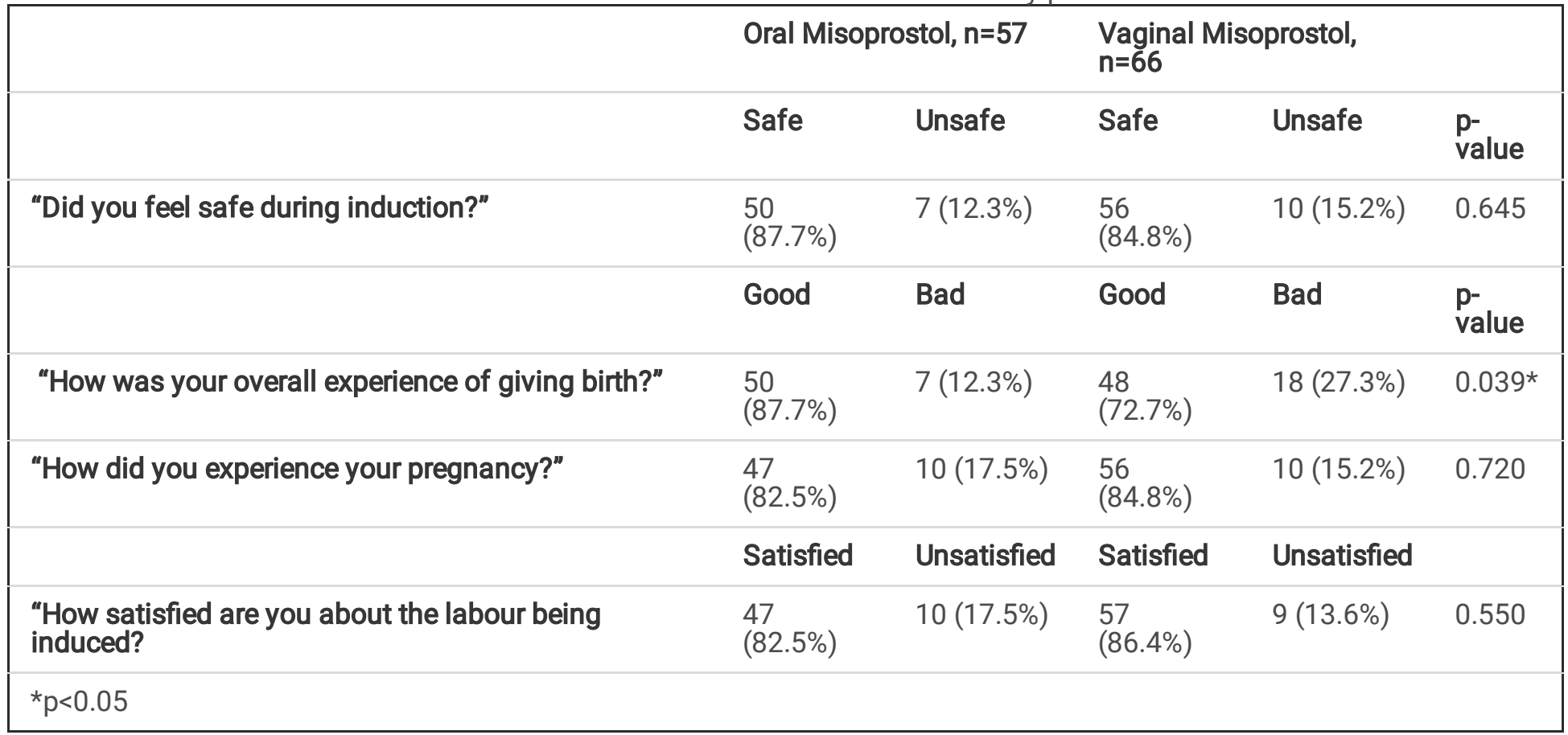

Figures 


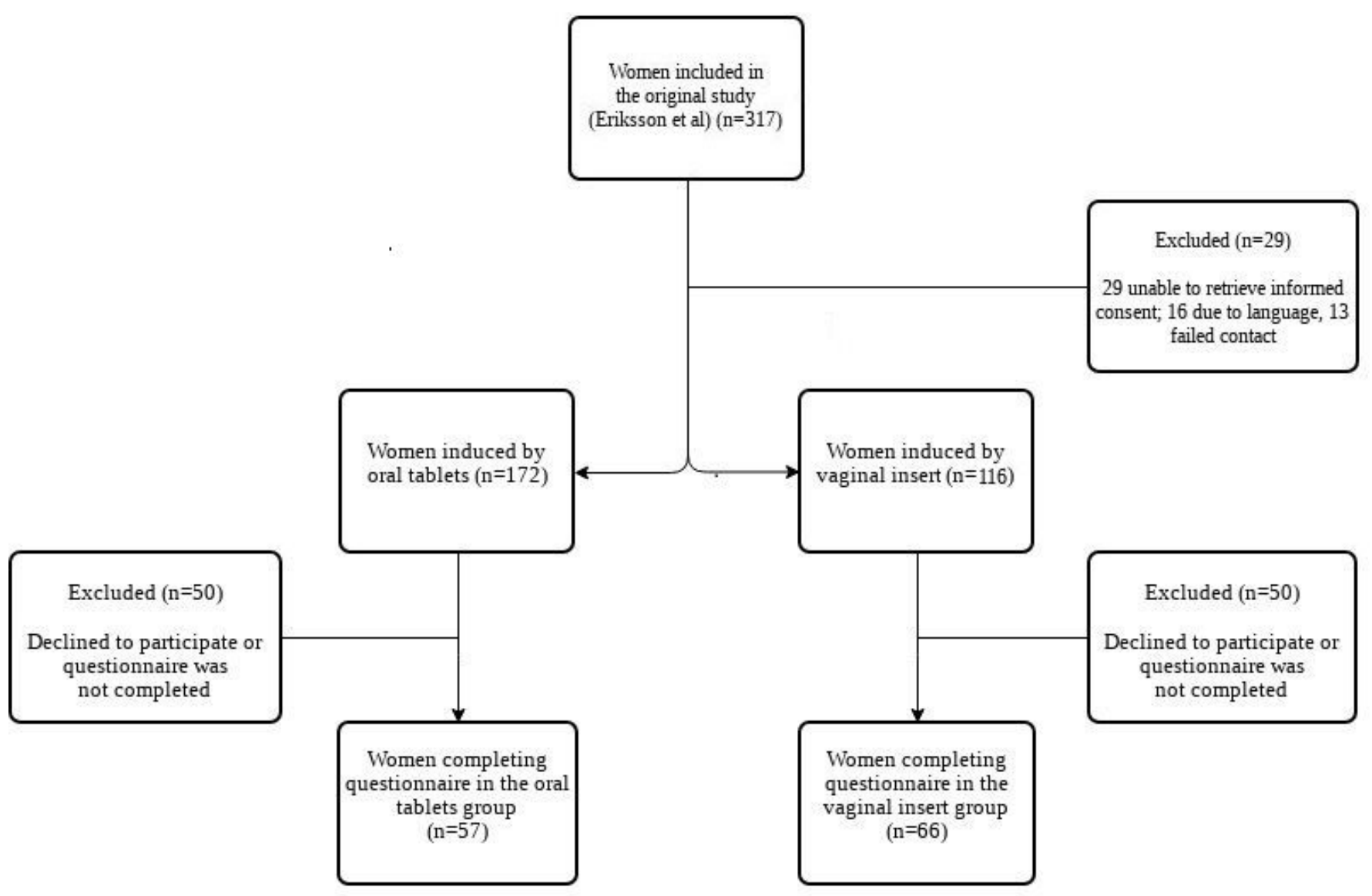

Figure 1

Flow chart 


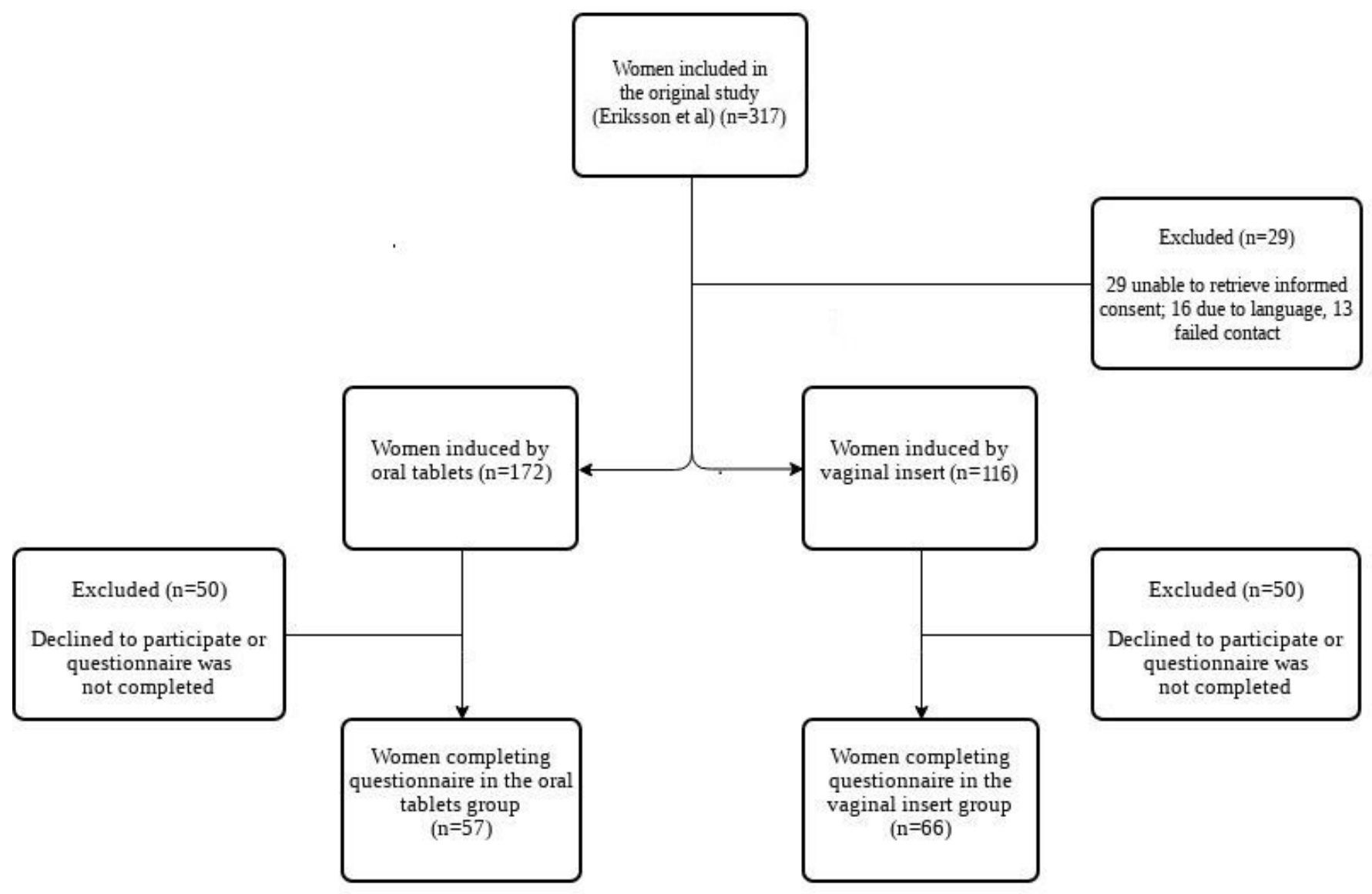

Figure 1

Flow chart

\section{Supplementary Files}

This is a list of supplementary files associated with this preprint. Click to download.

- questionnaire.docx

- questionnaire.docx 